\title{
The Effects of Using Internet-Based Export Marketing Information Sources on Export Market Growth Capability
}

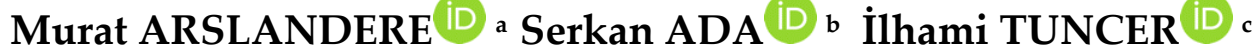 \\ a Karamanoğlu Mehmetbey University, School of Applied Sciences, Karaman, Turkey. muratarslandere01@gmail.com \\ b Karamanoğlu Mehmetbey University, Faculty of Economics and Administrative Sciences, Karaman, Turkey. serkanada@kmu.edu.tr \\ c Karamanoğlu Mehmetbey University, Faculty of Economics and Administrative Sciences, Karaman, Turkey. ituncer@kmu.edu.tr
}

\begin{tabular}{ll}
\hline ARTICLE INFO & ABSTRACT \\
\hline Keywords: & $\begin{array}{l}\text { Purpose - Using internet-based sources in obtaining information in export markets is prevalently } \\
\text { preferred as it provides fast access and cost advantages. In this study, firstly all internet-based export } \\
\text { Exporting }\end{array}$ \\
$\begin{array}{l}\text { Internet based export } \\
\text { marketing information sources } \\
\text { based export market information sources on obtaining new market knowledge and (ii) the effects of } \\
\text { obtaining new market knowledge on export market growth capability were empirically investigated. }\end{array}$ \\
$\begin{array}{l}\text { Design/methodology/approach - Hypotheses were tested with the data collected from 174 exporting } \\
\text { New market growth }\end{array}$ & $\begin{array}{l}\text { firms by means of a structured questionnaire. The data were analyzed by using the SmartPLS 2.0 } \\
\text { software. }\end{array}$ \\
Structural equation modeling & $\begin{array}{l}\text { Findings - The findings revealed that usage of internet-based export marketing information sources } \\
\text { in obtaining information in international markets has a positive effect on obtaining new market }\end{array}$ \\
keceived 30 July 2020 & $\begin{array}{l}\text { knowledge. The results also showed that obtaining new market knowledge has a positive effect on } \\
\text { growth capability in the export market. } \\
\text { Revised 17 November 2020 } \\
\text { Discussion - As far as the previous literature is concerned, there is no empirical study in the literature } \\
\text { which showed the internet-based sources of data on export markets as a whole and examined the } \\
\text { effects of these factors on new market knowledge and export market growth capability. This study } \\
\text { contributes to the literature by filling this gap. In this study, it was determined that using internet- } \\
\text { based information sources for obtaining export market information has an effect on obtaining new } \\
\text { market knowledge. Additionally, it was found that using internet-based export market information } \\
\text { sources positively influence export market growth capability. }\end{array}$ \\
Article Classification: &
\end{tabular}

\section{Introduction}

The importance of information in firm activities has been a topic that is focused on for more than a hundred years since the first observations and theoretical initiatives regarding management and organizational behavior emerged (Laudon \& Laudon, 1999). Ambiguous conditions in the market have relatively increased in abundance today in comparison to the past. Examples of factors that trigger these uncertainties may be listed as increased competition, deficiency of raw materials, instability of political relations, technological factors that are rapidly changing and developing and international-scale macroeconomic changes. These uncertainties also make it difficult for managers to make marketing decisions. For overcoming these increased difficulties, it has become more important in comparison to the past to reach more and accurate information effectively and on time (Shukla, 2008). In order to be able to develop action plans and marketing strategies in terms of determining customer needs and meeting these needs, firms have to collect information on the customers, competitors and other factors in the market. Especially as firms become national and international, the significance of such information is increases over and over (Malhotra \& Birks, 2007).

In today's world, more selective and responsible customers, globalized markets, increased supply in comparison to the past due to industrial production and development of logistics practices have increased competition on a high level. For these reasons, in addition to national markets, firms also aim to enter international markets. In this context, exporting becomes an important practice. Kotler and Armstrong (2013) (2013) argue that the easiest and fastest way to open an international arena for companies is to export. Exports,

\section{Önerilen Atıf/ Suggested Citation}

Arslandere, M., Ada, S., Tuncer, İ. (2020). The Effects of Using Internet-Based Export Marketing Information Sources on Export Market Growth Capability, Journal of Business Research-Turk, 12 (4), 3333-3349. 


\section{Arslandere - S. Ada - İ. Tuncer 12/4 (2020) 3333-3349}

on the other hand, are divided into two as indirect and direct exports. At the outset, firms make indirect exports by using intermediaries, while they directly export by carrying out their export transactions and increase their profits along with acquiring market information. At this point, it should be considered as an important element on behalf of companies that want to obtain export market knowledge and grow with export. Consequently, both before and after firms enter foreign markets, in order to expand and achieve sustainable operations, they have to enter an effective process of information collection. According to Craig and Douglas (2006), as firms push the boundaries of the geography of their operations to utilize growth opportunities, they have to collect information from broader and more diverse markets. This situation is increasingly making it a necessity to conduct research on foreign and remote markets in the Far East, Middle East, Latin America and Africa. So, this presents a set of difficulties in terms of not only collecting accurate and reliable information on existing behavioral patterns fast and in a cost-effective manner but also predicting responses to new and unfamiliar stimuli and interpreting their outcomes regarding marketing strategies. According to Köksal (2008), one of the most important conditions of being able to make healthy marketing decisions is obtaining information in the export marketing arena. With the help of this information, managers can follow up on market changes, produce responses to these changes and create productive and fast solutions to marketing problems. Information production, which allows making the right decision while growing in the international scene, is increasingly becoming more critical.

While managers are evaluating information, their consideration of the factor that may affect the nature and amount of the information is one of the preliminary conditions of effective and timely information collection. These factors include whether or not the information is available and can be obtained on time, whether or not it is effective in terms of the cost of the utility to be obtained, as well as its cost (Leonidou \& Theodosiou, 2004). In this context, attention should be paid to effective management of the information collection process especially regarding international markets. This is because problems that are experienced in accurately and timely access to information on international markets are some of the most frequently mentioned obstructions in exports (Azzi da Silva \& da Rocha, 2001; Tesfom \& Lutz, 2006; Walters, 1996). Reliable and up-to-date information is an important and indispensable condition for being able to achieve effective job planning. In the case that this condition is not met, many opportunities and threats in international markets will be ignored, and unsuccessful activities will emerge. For these reasons, information acquisition should be a priority for not only firms that do not have much international market experience but also those that are experienced internationally (Walters, 1996).

With the fast development of technology especially in the last 50 years, several developments have occurred among firms. These are issues such as mass production and being able to achieve flexible production by considering customer segmentation. Of course, these developments emerged in not only production but also marketing, finance and other activities. Advancements in technology have increased the importance, scope, effectiveness and efficiency of collecting marketing information. One of the most important elements in the developments in technological factors is the internet. Porter (2001) stated in a general perspective of a firm that, by speeding up the real-time information exchange of the internet and making it easy, improvements are achieved along the entire value chain for almost all firms and sectors. Usage of the internet in collecting market information has become inevitable. As today's firms constantly include all cost, quality and speed in their agenda, they do not neglect utilization of the opportunities to be provided for them by the internet (Kotler \& Keller, 2016; Malhotra \& Peterson, 2001; Poynter, 2010).

Considering also the great significance of the exports market in today's world, the importance of researching the contribution of information gathering from internet-based information sources in the exports market in today's digital age on an empirical level is clear. The web and social media provide a highly rich source of information for especially firms. In today's economy where competition is intense, utilization of these information sources by firms will create significant advantages. This study will empirically measure the perceptions of firms on utilization of such sources in the export market and see whether or not it affects export market growth capability.

The remainder of this paper is organized as follows. Next section is devoted to the theoretical framework and hypotheses development in which we propose the research model and hypotheses with theoretical arguments. Following this section, we provide explanations on the methods to be used to collect data and test the structural and measurement model proposed in the paper. Finally, we presented findings from the data 
analysis. The paper ends with the conclusion and discussions on the possible contribution and implications of this research.

\section{Theoretical Framework and Hypotheses Development}

Considering the fact that the importance of the internet in today's digital transformation age is on undeniable levels, with the additional fact that export has a large effect in the context of growth and stable operation of firms in the world that is looking for solutions to narrowing domestic markets and being globalized into a single market, and finally considering that information is perhaps the most important resource for firms, it is important to empirically study and reveal the effects of internet-based export marketing information sources on obtaining new market knowledge and growth in exports. Some studies in the literature (Hart \& Tzokas, 1999; Köksal, 2008; Souchon \& Durden, 2003; Theodosiou \& Katsikea, 2013; Yeoh, 2000) have shown that collecting information on exports has an effect on export performance. Additionally, Moen et al. (2008) has shown that usage of information and communication technologies in information research has an effect on getting new market knowledge in international markets. In addition, although some studies have shown empirically that the internet is used with other sources to obtain export marketing information (Köksal, 2008; Theodosiou \& Katsikea, 2013), there is no study in the literature which showed all of the internet-based export marketing information sources with all sub-dimensions, and the affect of using these sources on getting new market knowledge and on growth in the export market. Our study is significant in terms of filling this gap. In addition to the literature review, interviews were carried out with experts in the sector, and opinions were obtained regarding the internet-based data sources that are used in collecting export market information, the effects of these on new market knowledge and the relationship between new market knowledge and export market growth capability. Therefore, the following conceptual model is proposed, based on the studies in the prior literature as well as the opinions of the experts in the sector:

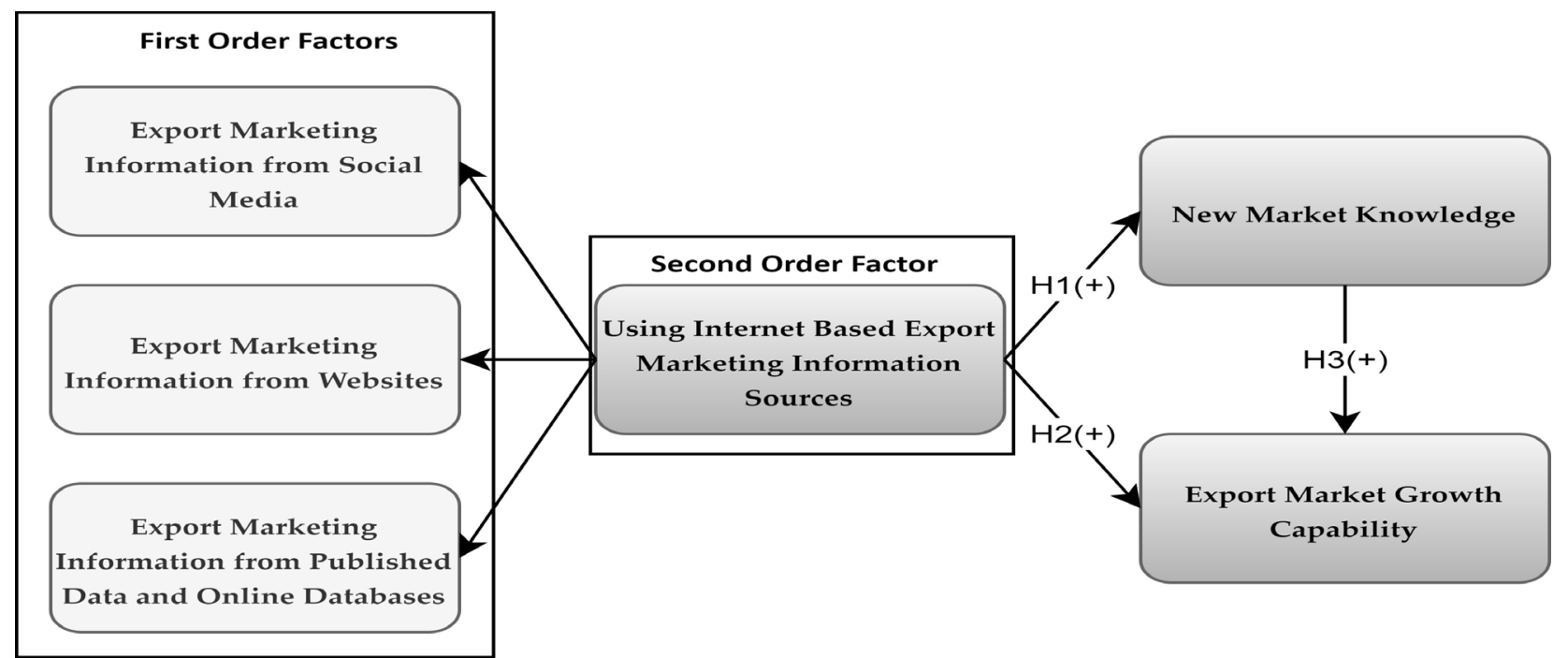

Figure 1: Conceptual Model

\subsection{Export Marketing Information}

Marketing information systems (MIS) are used in firms for obtaining information regarding marketing activities. An MIS consists of a set of procedures and methods for regular, planned collection, analysis and presentation of information to be used in marketing decisions (Mochtar \& Arditi, 2002). Marketing intelligence, marketing research, decision support systems and in-firm records are used within the scope of an MIS (Kotler \& Armstrong, 2003). In marketing knowledge, marketing research and marketing intelligence are usually concepts that are close to each other and often confused. In fact, while both involve information collection and information provision activities for managers to make effective and correct marketing decisions, they are different in terms of three aspects. These are information flow, the type of information that is provided and usage of information. A marketing intelligence system consists of a set of procedures and resources that are used to obtain daily information about developments in the marketing scene (Kotler, 1997). For this reason, marketing intelligence facilitates constant flow of information regarding a very diverse set of market events that might affect the competitive power of the firms, and therefore, its marketing activities. Information is 
based on observations and mainly explanatory. In general, its goal is to provide managers with general explanatory information regarding an ongoing competitive market issue. In comparison to this, market research activities are related to collection and analysis of data that are related to precise research questions such as effectiveness of advertising or approval of a new product. This is why information is intermittent and planned. A piece of market research information corresponds to focused goals and a defined target. The information that is collected should be clear, measured carefully, checked and analyzed, and the outcomes that emerge should support elimination or reduction of the uncertainty of the process of decision-making by managers (Le Bon \& Merunka, 2006).

The concept of export marketing information is used and analyzed by international marketing researchers (Leonidou \& Theodosiou, 2004; Souchon \& Diamantopoulos, 1996; Williams, 2006). In exports, marketing knowledge usually coincides with definitions of marketing research and market intelligence that contain all aspects of information collection (Diamantopoulos \& Souchon, 1999). Exporting firms perform the act of direct information collection from person to person involving foreign distributors, agencies, customers and representatives. Likewise, they attend expositions, exhibitions and trade missions to collect information about international markets (Leonidou \& Theodosiou, 2004). In addition to this, sources that are used to collect information about export markets also include supply interfaces (bankers and suppliers), specialized magazines and research, other firms, industry associations, state publications and internet-based electronic sources and databases (Julien \& Ramangalahy, 2003).

According to Douglas and Craig (1989), especially after 1960s, with the desires of the United States, Japan and Europe to operate internationally as a search for a solution to narrowing domestic markets, the phenomenon of operating in international markets has gained significance. Collecting information in international markets also plays a vital role as firms globally expand (Douglas \& Craig, 2006), and it has an important role regarding easy and effective decision-making in marketing (Kumar, 2006).

According to Kotler and Armstrong (2003), the need for export information may be considered under four different categories. The first is the macroeconomic aspect that occurs outside the control of the decisionmakers and covers threats and opportunities regarding international markets, the second is the task environment-related aspect that contains factors close to the firm towards meeting foreign customer needs in the best way, the third is the aspect related to the market where the firm operates or that contains the export market characteristics it wants to show, and finally, the fourth is the mix of marketing that consists of variables that are used in the way of the firm's reaching the point it targets in the market and it can control.

While information collection for firms may be categorized as official (for example, focus group meetings) or unofficial (interaction of the sales specialist with customers, etc.), it may also be classified as information from internal sources(financial statements, etc.) and from external sources (meetings with potential customers, etc.) (Leonidou \& Theodosiou, 2004). Additionally, information that is obtained may also be divided into two groups as primary data sources that are used directly by the firm with methods such as surveys and secondary data sources that are involve results of research previously conducted by other organizations (Malhotra \& Birks, 2007). All mentioned types of data sources are used to obtain export marketing information (Leonidou \& Theodosiou, 2004; Malhotra \& Peterson, 2001).

Issues that need to be considered in the process of obtaining information in international markets are different to national practices in some respects. These are factors such as cultural, racial, climatic, economic, religious, historical and linguistic differences (Kumar, 2006). At this point, firms that are doing marketing research need to also consider these factors, and in obtaining market information, they need to spread their scope to a broad area to contain not only customers but also economic, social and other factors that will affect customers (Malhotra \& Birks, 2007).

The constantly changing conditions in today's age of globalization pose new difficulties for firms. We face an element as established methodologies that must be changed based on newer and emerging research options and conditions (Sinkovics et al., 2005). In this context, usage of the internet for obtaining information in international markets has ascended into a significant position (Craig \& Douglas, 2001). 


\subsection{Internet-Based Export Marketing Information Sources and New Market Knowledge}

The role of the internet is constantly increasing in terms of obtaining export marketing information (Köksal, 2008). With the help of these data that can be obtained faster and with lower costs, firms will be able to access information about new markets, and they will mobilize their own strategies by using this information to be able to grow in these new markets in question. In this context, the types of sources that could be used for obtaining export marketing information from internet-based sources are explained below, and then, the research hypotheses are presented.

\subsubsection{Export Marketing Information on Internet Based Data Sources}

The vast majority of the population of the US and Europe have access to the internet. According to the British Market Research Association (BMRA) and the World Association of Opinion and Market Research (ESOMAR), these regions also constitute a significant part of the purchasing power of the world. Additionally, internet usage speed is constantly becoming faster in Asia and other regions. This prevalent adoption of the internet has made a large proportion of the population accessible over the internet and allowed online acquisition and assessment of needs and preferences of a significant and representative population of consumers (Agrawal et al., 2004). Moreover, the websites and e-commerce sites of competitor firms are also utilized as data sources where important information can be accessed by marketing researchers in the virtual world (Akın, 2019; Hair et al., 2018; Kotler \& Keller, 2016; Malhotra \& Peterson, 2001; Mochtar \& Arditi, 2002; Poynter, 2010; Wedel \& Kannan, 2016). The following sections discuss internet-based sources of export marketing information. These sources are social media, websites, e-publication data and online databases.

Export marketing information from social media: In the process of data collection in international markets, advanced internet technologies have had a significant contribution (Craig \& Douglas, 2001). One these technologies are social media. Studies on value creation on social media platforms in the context of marketing intelligence and new market knowledge have become the fruit of the digital revolution in today's world (Lamberton \& Stephen, 2016). Social media technologies have been a mediator for firms to reevaluate their approaches regarding collecting intelligence about their customers (Teubner, 2007) and their competitors (Itani et al., 2017) for getting new market knowledge. Social media has turned into an indispensable information ecosystem for today's firms. This ecosystem contains consumers, firms, governments, non-profit organizations, etc. Firms see these platforms as a rich source of information in terms of product design and innovation, consumer and stakeholder relations and marketing. For them, social media is a main component of a future generation of a firm intelligence platform (Zeng et al., 2010).

Social networks, blogs and other types of social media constitute highly rich sources of data for firms. With the help of these social media instruments, consumers are able to comfortably discuss their likes and dislikes about the firm itself and its products (Stokes, 2011). Considering that foreign customers are important sources of data for firms (Leonidou \& Theodosiou, 2004), it is needed to utilize these data and carefully focus on these for the export market. According to Quinton and Wilson (2016), social media helps sales representatives gain information by doing research among cultures and on an international level. According to Kotler and Keller (2016), firms may gather effective and useful information from social networks and blogs. For example, information on what is being talked about regarding the products of the firm, personal experiences of customers about the brand or the product, etc. may be gathered from social media tools such as Twitter and Facebook, blogs, forum sites (Hair et al., 2018; Poynter, 2010) and video sharing platforms (Malhotra, 2018). Additionally, effective information may be gained via social media regarding the firm's competitors (Itani et al., 2017). When considering the fact that the costumers and rivals are an important sources of export marketing information (Leonidou \& Theodosiou, 2004), all of these sources can be used by exporting firms for acquiring new market knowledge.

Therefore, with the help of these data that are obtained, information may be gathered regarding international markets, and new horizons may be opened for exporting. Marketing researchers will be able to comfortably use these new social networks to expand the limits of their research. According to Malhotra (2018) these social communities provide new opportunities to understand, explain, predict and influence the behaviors of consumers in the market. Therefore, these may be used in various marketing research practices such as segmentation, concept testing, idea creation, product development, brand launches, integrated marketing 
communication and appraisal. Additionally, and at the same time, from these platforms, firms may obtain information about their competitors in the international scene and their products.

Export marketing information from websites: Customers and competitors are among the factors that need to be focused on in the process of obtaining information regarding the export market (Wren et al., 2000). With the help of the web, it has been possible to access highly diverse and abundant market data regarding purchasers, sellers and distributors (Shukla, 2008). For export market information, foreign customers are a significant source of data in the context of market trends, preferences and behavioral styles. Moreover, competitor firms may also provide useful information in addition to this information (Leonidou \& Theodosiou, 2004). The internet helps firms analyze the marketing mix strategies of their competitors by marketing research. Many firms have websites to attract their customers to the firm, and these websites include useful information for competitors to getting new market knowledge. The website of a firm usually contains a detailed list of its products, and most of the time, the price that is asked for these products. Likewise, these websites also reveal information regarding how a firm introduces its products and services (Skurpel, 2016). At this point, it would be useful to talk about business-to-business marketing research (Malhotra \& Birks, 2007). In b2b marketing research where firms study each other, while the studied party may be competitor firms, it may also be other firms that are the customers of the firm itself. In addition to such websites, as another source of marketing information, useful information may also be obtained from e-commerce sites (Yang \& Tang, 2003). For example, with its 278 million active customers, Amazon may be utilized as not only a prominent e-commerce platform but also a source where useful information can be reached regarding products, firms, customers, purchasing behaviors, etc. (Wedel \& Kannan, 2016). Examples of such sites may also include those like Alibaba, TradeKey, TradeBoss and ECPlaza (Akın, 2019). According to Craig and Douglas (2005), on websites, customer behaviors may be monitored and used in international marketing research for obtaining new market knowledge. Furthermore, Kotler and Keller (2016) stated that firms may obtain useful information from the websites of their competitors. In summary, in line with these explanations, it can easily be stated that the websites of competitors and customer leads, and e-commerce sites can be used to obtain export marketing information.

Export marketing information from e-published data and online databases : E-published and online data constitute the most frequently utilized data sources in marketing research. Their possibility of access from low-cost and reliable sources is one of the most important factors that attract firms. E-published and online data refer to data that are collected and reported towards a certain purpose. Institutions and organizations that offer sources of e-published and online data include local authorities, regional and national governments, the EU, non-profit organizations (e.g. Chambers of Commerce), trade unions and occupational organizations, commercial publishers, investment brokering firms and professional marketing research firms for acquiring new market knowledge (Fries, 1982). For obtaining information on foreign markets, states' online statistics sites (Tarka, 2018) databases and country reports (Craig \& Douglas, 2005; Malhotra, 2018) (e.g. International Trade Administration - www.ita.doc.gov, World Factbook- The CIA publishes) are also being used. In addition to these, the online statistics sites and databases of national and international unions (Craig \& Douglas, 2005) (e.g. United Nations - www.un.org) are also utilized as internet-based sources of data. Moreover, tools that are used as internet-based sources of data for obtaining new market knowledge in international market also include online databases that require paid membership and provide information on international firms and markets (Hair et al., 2018; Malhotra, 2018) (e.g. The Economist Intelligence Unit - www.eiu.com, Euromonitor -www.euromonitor.com) and consignment sites (Akın, 2019) (e.g.Trade Atlas, Great Export Import, Panjiva, Import Genius).

The prevalence of the data that are offered in the form of ready reports as mentioned above in North America and Europe is much superior to those in several developing countries around the world. The existence of more than 4000 full-service market research suppliers is another advantage of North America (Young \& Javalgi, 2007). These data sources have priority in especially countries that the firm is less familiar with and in utilization of opportunities at an early stage of market development such as the case of market countries that are developing. These sources allow access to fast and valuable new market knowledge by providing an easy and fast way to reach some understandings on the market environment in a foreign country (Craig \& Douglas, 2005). Information search in international markets is a way of obtaining information and contributes to new market knowledge (Moen et al., 2008). The internet is one of the sources that are used to obtain export market 


\section{Arslandere - S. Ada - İ. Tuncer 12/4 (2020) 3333-3349}

information (Köksal, 2008; Theodosiou \& Katsikea, 2013). Also Julien and Ramangalahy (2003) state that some of the information sources utilized by exporting firms are public and private databases and the internet. From this point of view, e-published data and online databases is easily being considered as an important sources of export marketing information.

Market knowledge is the greatest value of modern businesses, and is one of the best ways to maintain their sustainability. In order to compete effectively, firms need to use their existing knowledge and acquire new knowledge to position themselves appropriately in the markets they choose (Hou \& Chien, 2010). Similarly, Probst et al. (1998, p. 247) state that "to develop organizational knowledge leading to a sustainable competitive advantage, the incorporation and integration of information which is available outside the borders of the company are a necessary condition". Therefore, the way to obtain new market information and increase the existing information with integration is to enrich the information sources related to the targeted market. According to Moen et al. (2008), new market knowledge includes variables of ability to operate in new markets and knowledge of competitor strategies. Also Perreault et al. (2013) state that it is extremely important to obtain new market knowledge by gathering information about customer needs and requirements, especially in the entry to international markets. Köksal (2008) empirically showed that exporting companies use internet as a source for market knowledge of export marketing. Also Theodosiou and Katsikea (2013) empirically showed that usage of formal/documented export information sources which includes internet, has a positive impact on acquisition of market knowledge for export marketing. In accordance with the explanations above, the following hypothesis is proposed:

Hypothesis 1: Using internet based export marketing information sources positively impacts new market knowledge.

\subsection{Export Market Growth Capability}

According to Ansoff (1988), market growth is based on four main strategies that are original and well-known, which are created by introducing existing and new products into existing or new markets. These strategies are market penetration where the current product is introduced to the current market, product development where the new product is introduced into the current market, market development where the current product is introduced into the new market, and finally diversification where the new product is introduced into the new market. International marketing researchers also widely use the concept of market growth in their studies (Houghton \& Winklhofer, 2004; Lim et al., 1993; Toften \& Hammervoll, 2011).. Accordingly, important strategies of firms include the development of the product's market and penetration into new markets (Houghton \& Winklhofer, 2004). Export performance is an important factor in development and growth of these markets. While there is no consensus on the best way to measure export performance, the general idea is that there are two main export performance criterion categories. These are financial and non-financial export performance criterion. One of the financial export performance criteria is export market growth (Zou \& Stan, 1998). According to Bianchi and Mathews (2016), export market growth can be subdivided into new customers in new countries, new customers in existing export markets and growth in existing export customers, in line with the strategies of entering existing or new markets suggested by Ansoff (1988). Export market growth capability is related to the ability to materialize these strategies. In this study, export market growth capabilities are classified based on these criteria.

If firms want to exceed the national borders and grow in international markets, they have to collect effective and productive information (Kumar, 2006). According to Nijssen et al. (1999), a high-quality information searching process will increase the quality of the decisions that are made, and therefore, increase the performance in international markets. Obtaining sufficient amounts of information and using it effectively is an indispensable factor for the firm to grow and expand in exports in foreign markets and operations (Leonidou \& Katsikeas, 1996). Collecting and using export market intelligence is an important factor in achieving successful export performance indicators (Diamantopoulos \& Souchon, 1999; Julien \& Ramangalahy, 2003). Collecting marketing intelligence in foreign markets and obtaining information about new markets constitute a prominent factor in overcoming psychological obstacles to exporting and practicing strategic marketing methods for the exporting firm (Cadogan et al., 2012). Firms that aim to enter foreign markets and grow should pay importance to market intelligence and their capability in obtaining information on new markets. This is because effective and productive exporting requires explanatory and detailed 
information on the unique commercial practice, cultures and competitors in each country's market. On time and correct marketing decisions will play a determining role in a dominant way only by accessing accurate and relevant information in each country's market and using this information by analysis over export performance (Hughes et al., 2008). Several studies in the literature have shown and suggested that collecting information for exports has an effect on export market growth (Mathews et al., 2016; Mathews \& Healy, 2006). Additionally some studies in the literature (Hart \& Tzokas, 1999; Köksal, 2008; Souchon \& Durden, 2003; Theodosiou \& Katsikea, 2013; Yeoh, 2000) have shown that collecting information on exports has an effect on export performance. Also, Moen et al. (2008) has shown that usage of information and communication technologies in information research has an effect on getting new market knowledge in international markets. Accordingly, the following hypotheses are proposed:

Hypothesis 2: Using internet based export marketing information sources positively impacts export market growth capability

Hypothesis 3: New market knowledge positively impacts export market growth capability

\section{Research Methodology}

The necessary information about sampling, data collection, measurement and the research methodology applied to the test hypotheses are explained in the following sections.

\subsection{Measurement}

Three constructs were measured in this study: Internet based export marketing information sources, new market knowledge and export market growth capability. Internet based export marketing information sources are measured as a second-order construct which is composed of three dimensions: export marketing information from social media, export marketing information from e-published data and online databases and export marketing information from websites. These constructs were measured by multiple items, asking the level of participation for each item in the statement "we use the item to obtain export marketing information" with using a five-point Likert-type scale with measure indicators ranging from 1 ('strongly disagree') to 5 ('strongly agree'). Some of the items were taken from previously validated scales in the marketing literature and adapted. The rest of the items were sourced from the international marketing literature and newly developed. In accordance with the suggestion of Nunnally (1978), a minimum of three items were used per construct with a view to ensure adequate reliability. Table 1 shows the measurement items together with the sources from which they were taken and adapted or newly developed.

We intended to gauge the extent of new market knowledge and export market growth capability in comparison to those of its major rivals in the export market. So the new market knowledge and export market growth capability constructs were measured with multiple items, using a five-point Likert-type scale $(1=$ "much worse," 5 = "much better") to register the response on each item.

Table 1. Measurement Items

\begin{tabular}{|c|c|c|c|c|}
\hline Construct & Item & Measurement items & Source & \\
\hline \multirow{3}{*}{$\begin{array}{l}\text { Export Marketing } \\
\text { Information from } \\
\text { Social Media }\end{array}$} & SM1 & $\begin{array}{l}\text { We use social networks (Facebook, } \\
\text { Twitter, Instagram, LinkedIn etc.) in } \\
\text { export marketing information. }\end{array}$ & $\begin{array}{c}\text { (Brennan et al., } \\
\text { 2015; Hair et al., } \\
\text { 2018; Kotler \& }\end{array}$ & \multirow{3}{*}{$\begin{array}{c}\text { Newly } \\
\text { developed }\end{array}$} \\
\hline & SM2 & $\begin{array}{l}\text { We use video sharing platforms } \\
\text { (Youtube etc.) in export marketing } \\
\text { information. (Example: video sharing of } \\
\text { competitors about their products) }\end{array}$ & $\begin{array}{l}\text { Keller, 2016; } \\
\text { Malhotra \& } \\
\text { Peterson, 2001; } \\
\text { Poynter, 2010; }\end{array}$ & \\
\hline & SM3 & $\begin{array}{l}\text { We use blog and forum sites in export } \\
\text { marketing information. }\end{array}$ & $\begin{array}{l}\text { Wedel \& Kannan, } \\
\text { 2016) }\end{array}$ & \\
\hline $\begin{array}{l}\text { Export Marketing } \\
\text { Information from } \\
\text { E-Published Data }\end{array}$ & DS1 & $\begin{array}{l}\text { We use states' official statistics sites, } \\
\text { databases and country reports for } \\
\text { export marketing information. } \\
\text { We use online statistics sites, databases }\end{array}$ & $\begin{array}{l}\text { (Akın, 2019; Craig } \\
\text { \& Douglas, 2005; } \\
\text { Kotler \& Keller, } \\
\text { 2016; Malhotra \& }\end{array}$ & Newly \\
\hline
\end{tabular}


M. Arslandere - S. Ada - İ. Tuncer 12/4 (2020) 3333-3349

and Online

Databases

ratabs

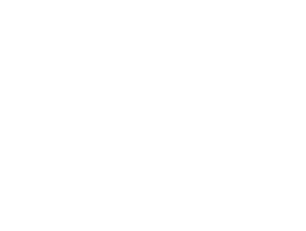

$\begin{array}{ccl} & \text { W1 } & \begin{array}{l}\text { We analyze competitors' websites in } \\ \text { export marketing information. }\end{array} \\ \begin{array}{c}\text { Export Marketing } \\ \text { Information from } \\ \text { Websites }\end{array} & \text { W2 } & \begin{array}{l}\text { In export marketing information, we } \\ \text { examine our client websites. }\end{array} \\ & \text { W3 } & \begin{array}{l}\text { We review e-commerce sites } \\ \text { (Alibaba.com etc.) in export marketing } \\ \text { information. }\end{array}\end{array}$

DS3 membership in export marketing information and provide information about foreign companies. international associations in export marketing information.

We use online databases and bill of lading sites that require paid
Peterson, 2001; Mochtar \& Arditi, 2002; Tarka, 2018; Young \& Javalgi, 2007)

(Akın, 2019; Hair
et al., 2018; Kotler
\& Keller, 2016;
Malhotra \&
Peterson, 2001;
developed
Mochtar \& Arditi,
2002; Poynter,
2010; Wedel \&
Kannan, 2016)

(Akın, 2019; Hair et al., 2018; Kotler \& Keller, 2016;

Malhotra \&

Peterson, 2001

Mochtar \& Arditi

2010; Wedel \&

Kannan, 2016)

developed

*Evaluate the following expressions about export according to your competitors closest to your scale.

\begin{tabular}{|c|c|c|c|c|}
\hline \multirow{3}{*}{$\begin{array}{l}\text { New Market } \\
\text { Knowledge }\end{array}$} & NML1 & $\begin{array}{l}\text { Knowledge of competitor } \\
\text { strategies }\end{array}$ & \multirow{3}{*}{ (Moen et al., 2008) } & \multirow{2}{*}{$\begin{array}{l}\text { Adapted } \\
\text { and Newly } \\
\text { developed }\end{array}$} \\
\hline & NML2 & $\begin{array}{l}\text { Knowledge of customer } \\
\text { demands and requests }\end{array}$ & & \\
\hline & NML3 & $\begin{array}{l}\text { Knowledge of ability to enter } \\
\text { and operate in new markets }\end{array}$ & & \multirow{4}{*}{ Adapted } \\
\hline \multirow{3}{*}{$\begin{array}{l}\text { Export Market } \\
\text { Growth } \\
\text { Capability }\end{array}$} & EMGC1 & $\begin{array}{l}\text { Capability to find new } \\
\text { customers in new countries in } \\
\text { exports }\end{array}$ & \multirow{3}{*}{$\begin{array}{l}\text { (Mathews et al., 2016; } \\
\text { Voorhees et al., 2017) }\end{array}$} & \\
\hline & EMGC2 & $\begin{array}{l}\text { Capability to find new } \\
\text { customers in countries } \\
\text { available for export }\end{array}$ & & \\
\hline & EMGC3 & $\begin{array}{l}\text { Capability to increase sales of } \\
\text { our current customers in export }\end{array}$ & & \\
\hline
\end{tabular}

\subsection{Pretest and Pilot Test}

The first version of the research tool was previously tested with 3 experts from the private sector related to the area of the study. Each participant was given a copy of the questionnaire by the researcher. They were asked to provide feedback on the clarity of the instructions, the layout of the questionnaire and the wording of the questions. In general, positive feedback was received, and no changes were made in the questionnaire. A pilot test was also performed with 20 questionnaire items. After seeing the positive statistical results of the pilot test, the authors continued the data collection.

\subsection{Sampling and Data Collection}

At the outset, minimum sample size was identified by using the table which was given in the Appendix (Hair et al., 2014). This table requires to select three parameters for identifying the minimum sample size. These parameters were selected as follows: (1) significance level $(p<0.05),(2)$ maximum number of arrows pointing at a construct (two), (3) minimum $R^{2}$ value (0.50). The table in the Appendix shows that the minimum sample size for this study should be '33', based on the selected values of the parameters at issue.

Target audience constituting the population of the current study was identified by taking export companies in various sectors into consideration. Respondents were selected from different sectors and different regions of Turkey in order to create a sample that represents the population. A questionnaire was applied to the willing participants by trained interviewers in October 2019. Since the data were collected before January 
1st, 2020, the requirement for Universtiy's ethics committee approval was waived. The participants were selected from the owners and decision-makers of export firms. Most of the surveys were applied in printed form. In order to increase the response rate, the surveys were also conducted as telephone and e-mail interviews. Among the 185 export firm owners/decision-makers reached to participate in the study, 174 usable responses were obtained. This was remarkably above the minimum sample size requirement.

\section{Data Analysis and Results}

The partial least squares (PLS) methodology with Smart PLS 2.0 was used in this study to test the proposed model and related hypotheses. The following sections present the results of the statistical analysis.

\subsection{Demographic Profile of the Sample}

Of the 174 responding firms, 4,6\% had 1-10 employees, $29,3 \%$ had $11-50$ employees, $41,4 \%$ had $51-200$ employees, and the remainder (24,7\%) employed more than 200 employees. Firms from different sectors were included in the sample. $24,1 \%$ of the firms included in the sample was from food sector, $9,8 \%$ was from machinery sector, $13,8 \%$ was from electronic sector, $27 \%$ was from textile sector, and the remainder firms $(25,3 \%)$ were from other sectors. In terms of the years of the sample firms' existence, $11,5 \%$ had $1-5$ years, $23,6 \%$ had 6-10 years, $15,5 \%$ had $11-15$ years, $15,5 \%$ had $16-20$ years, and the remaining firms (33,9\%) had more than 20 years of existence. As for the years of total export activity, $24,7 \%$ of the firms had $1-5$ years, $25,3 \%$ had $6-10$ years, $22,4 \%$ had $11-15$ years, $11,5 \%$ had $16-20$ years, and the remaining firms $(16,1 \%)$ had more than 20 years of total export activity.

Attention was paid so that the surveyed responders had knowledge about the subject, the surveys were implemented with participants in managerial positions (79,3\%)or company owners (20,7\%). In addition, most of the survey responders were male $(82,8 \%)$, while $17,2 \%$ of the sample consisted of the female responders. As for the education level, most of the responders in the sample were graduated from at least an undergraduate level program $(77,6 \%)$, while $9,2 \%$ possess a high school degree, and $13,2 \%$ possess an associate degree.

\subsection{SEM Analysis}

The model estimation process was carried out in the Smart PLS 2 software (Henseler et al., 2015). This study firstly analyzed the measurement for its validity. This step was followed by the analysis of the structural equation model to test the relationships hypothesized in the research model.

\subsubsection{Measurement Model Analysis}

With the help of confirmatory factor analysis, the convergent validity of each structure was tested. Test results related to the convergent validity of the constructs are given in Table 2. Examining the standardized factor loadings of each item in the measurement model, the reliability and the average variance extracted (AVE) for each construct were examined to evaluate the convergent validity.

A factor loading greater than 0.5 is considered a valid condition for item reliability (Hair et al., 2010).In this respect, the standardized factor loadings of each item were observed, and the reliability of the individual items was confirmed.

Cronbach's alpha coefficients for all constructs were above the stipulated level of reliability (0.70), and the AVE for each construct was higher than 0.50 (Fornell \& Larcker, 1981). As a result, the model satisfied the requirements for convergent validity. 
Table 2. Validity of Constructs

\begin{tabular}{ccccccc}
\hline Construct & Items & $\begin{array}{c}\text { Factor } \\
\text { loading }\end{array}$ & Std. Error & t-value & $\begin{array}{c}\text { AVE } \\
(>\mathbf{0 . 5})\end{array}$ & $\begin{array}{c}\text { Cronbach's } \\
\text { alpha }(>\mathbf{0 . 7})\end{array}$ \\
\hline Export Marketing Information & SM1 & 0.703 & 0.093 & 7.557 & 0.667 & 0.752 \\
from Social Media & SM2 & 0.854 & 0.040 & 21.537 & & \\
Export Marketing Information & SS1 & 0.883 & 0.023 & 39.015 & & \\
Drom E-Published Data and & DS2 & 0.756 & 0.131 & 5.775 & 0.624 & 0.722 \\
Online Databases & DS3 & 0.719 & 0.106 & 7.763 & & \\
Export Marketing Information & W1 & 0.875 & 0.051 & 15.626 & & \\
from Websites & W2 & 0.843 & 0.038 & 23.094 & 0.660 & 0.738 \\
& W3 & 0.710 & 0.064 & 11.142 & & \\
New Market Knowledge & NML1 & 0.824 & 0.047 & 17.631 & 0.728 & 0.813 \\
& NML2 & 0.864 & 0.042 & 20.666 & & \\
Export Market Growth & NML3 & 0.872 & 0.033 & 26.557 & & \\
Capability & EMGC1 & 0.879 & 0.039 & 22.782 & 0.744 & 0.826 \\
& EMGC2 & 0.920 & 0.021 & 44.214 & & \\
\hline
\end{tabular}

Table 3. Construct Cross-loadings

\begin{tabular}{cccccc}
\hline & SM & WEB & DS & NML & EMGC \\
\hline SM1 & $\mathbf{0 . 7 0 3}$ & 0.213 & 0.142 & 0.225 & 0.268 \\
SM2 & $\mathbf{0 . 8 5 4}$ & 0.430 & 0.260 & 0.219 & 0.284 \\
SM3 & $\mathbf{0 . 8 8 3}$ & 0.452 & 0.456 & 0.339 & 0.366 \\
W1 & 0.346 & $\mathbf{0 . 8 7 5}$ & 0.452 & 0.245 & 0.201 \\
W2 & 0.387 & $\mathbf{0 . 8 4 3}$ & 0.402 & 0.206 & 0.176 \\
W3 & 0.410 & $\mathbf{0 . 7 1 0}$ & 0.296 & 0.270 & 0.104 \\
DS1 & 0.109 & 0.200 & $\mathbf{0 . 7 5 6}$ & 0.274 & 0.305 \\
DS2 & 0.104 & 0.275 & $\mathbf{0 . 8 1 9}$ & 0.229 & 0.302 \\
DS3 & 0.525 & 0.542 & $\mathbf{0 . 7 9 4}$ & 0.510 & 0.476 \\
NML1 & 0.333 & 0.354 & 0.423 & $\mathbf{0 . 8 2 4}$ & 0.473 \\
NML2 & 0.266 & 0.230 & 0.420 & $\mathbf{0 . 8 6 4}$ & 0.541 \\
NML3 & 0.236 & 0.173 & 0.353 & $\mathbf{0 . 8 7 2}$ & 0.637 \\
EMGC1 & 0.403 & 0.154 & 0.432 & 0.584 & $\mathbf{0 . 8 7 9}$ \\
EMGC2 & 0.318 & 0.186 & 0.456 & 0.595 & $\mathbf{0 . 9 2 0}$ \\
EMGC3 & 0.248 & 0.181 & 0.355 & 0.489 & $\mathbf{0 . 7 8 4}$ \\
\hline
\end{tabular}

Discriminant validity was examined by comparing the square root of the AVE for each construct. If the square root of its AVE is higher than each correlation value with other constructs, discriminant validity is achieved (Fornell \& Larcker, 1981). The results are shown in Table 4 and indicated good discriminant validity.

Table 4. Square Root of AVE (Fornell-Larcker discriminant validity criteria.)

\begin{tabular}{cccccc}
\hline & EMGC & NML & DS & SM & WEB \\
\hline EMGC & $\mathbf{0 . 8 6 3}$ & & & & \\
NML & 0.647 & $\mathbf{0 . 8 5 3}$ & & & \\
DS & 0.483 & 0.466 & $\mathbf{0 . 7 9 0}$ & & \\
SM & 0.378 & 0.325 & 0.375 & $\mathbf{0 . 8 1 7}$ & \\
WEB & 0.200 & 0.293 & 0.477 & 0.466 & $\mathbf{0 . 8 1 2}$ \\
\hline
\end{tabular}

\subsubsection{Hypothesis Testing}

As summarized in figure 2 and table 5, all of the three hypothesized paths were significant. Using internetbased export marketing information sources was significantly and positively $(\beta=0.455, t=5.923, p<0.05)$ related to new market knowledge. Thus, hypothesis 1 was supported. 
M. Arslandere - S. Ada - İ. Tuncer 12/4 (2020) 3333-3349

Table 5. Summary of Hypotheses Testing Results

\begin{tabular}{|c|c|c|c|c|c|c|c|c|}
\hline & Hypothesis & & & $\begin{array}{l}\text { Original } \\
\text { Sample }\end{array}$ & $\begin{array}{c}\mathrm{T} \\
\text { Statistics }\end{array}$ & $\begin{array}{c}\text { P- } \\
\text { Values }\end{array}$ & $\begin{array}{c}\text { (STD } \\
\text { EV) }\end{array}$ & $\begin{array}{l}\text { Supporte } \\
\text { d }\end{array}$ \\
\hline H1 & $\begin{array}{l}\text { Using Internet Based } \\
\text { Export Marketing } \\
\text { Information Sources }\end{array}$ & $-->$ & $\begin{array}{l}\text { New Market } \\
\text { Knowledge }\end{array}$ & 0.455 & 5.923 & 0,000 & 0.077 & Yes \\
\hline $\mathrm{H} 2$ & $\begin{array}{l}\text { Using Internet Based } \\
\text { Export Marketing } \\
\text { Information Sources }\end{array}$ & $-->$ & $\begin{array}{c}\text { Export Market } \\
\text { Growth } \\
\text { Capability }\end{array}$ & 0.189 & 2.129 & 0,033 & 0.089 & Yes \\
\hline $\mathrm{H} 3$ & New Market Knowledge & $-->$ & $\begin{array}{c}\text { Export Market } \\
\text { Growth } \\
\text { Capability }\end{array}$ & 0.561 & 5.795 & 0,000 & 0.097 & Yes \\
\hline
\end{tabular}

The results further showed that using internet-based export marketing information sources was significantly and positively $(\beta=0.189, \mathrm{t}=2.129, \mathrm{p}<0.001)$ associated with export market growth capability, providing support for Hypothesis 2 . The results also revealed that new market knowledge was significantly and positively $(\beta=$ $0.561, \mathrm{t}=5.795, \mathrm{p}<0.001)$ related to export market growth capability. Hypothesis 3 was thus supported. Using internet-based export marketing information sources explained $20.6 \%$ of the variance in new market knowledge, and new market knowledge explained $44.7 \%$ of the variance in export market growth capability.

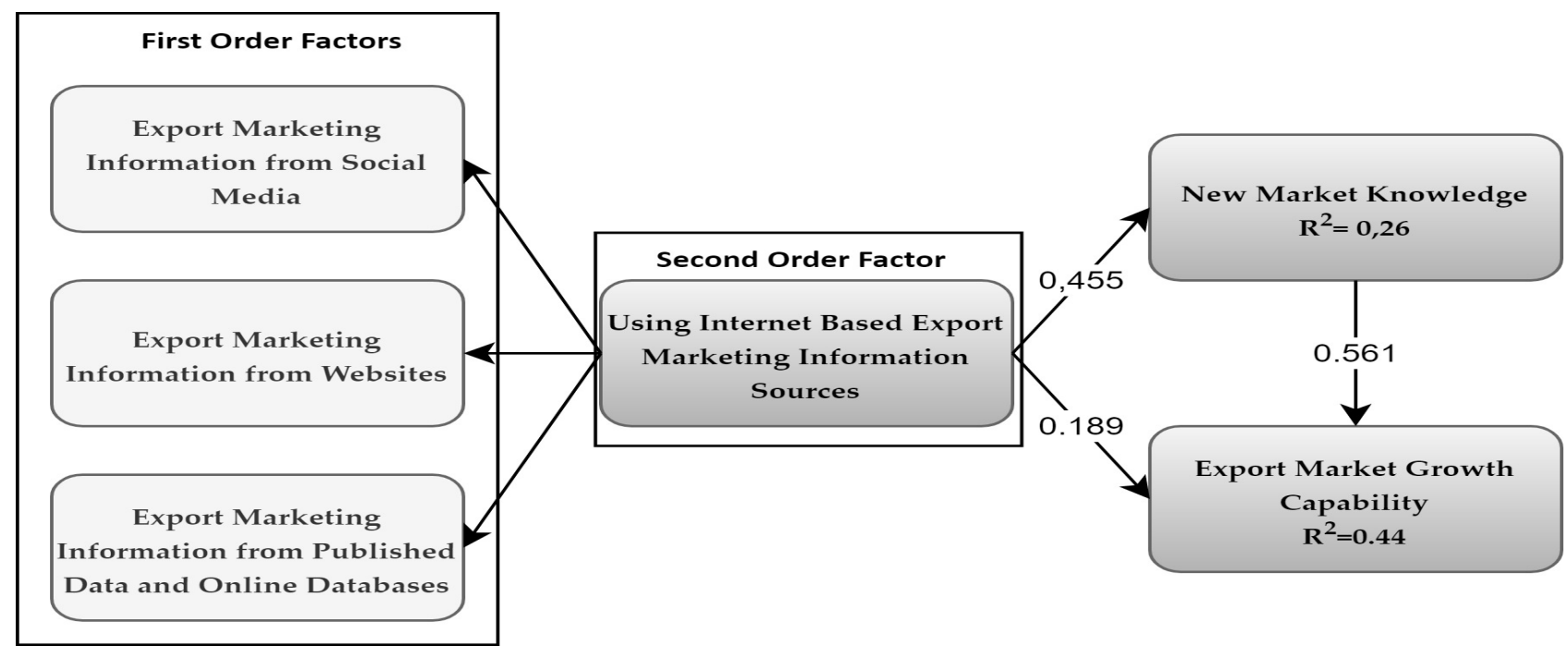

Figure 2. PLS Results of the Structural Model

\section{Discussion and Conclusion}

The purpose of this study was to investigate the effects of using internet-based sources in obtaining export marketing information among exporting firms in Turkey on obtaining new market knowledge, as well as the effects of obtaining new market knowledge on export market growth capability. To confirm the hypothesized research model, a field study containing exporting firms from different sectors and provinces in Turkey was utilized. The results on the findings that were obtained are discussed in the paragraphs below.

\section{Theoretical and Practical Implications}

The findings of this study provide significant results and recommendations for the theory, management and practitioners in the field of international commerce and marketing. In today's globalized business world where competition is intense, the role of the internet is undeniable. Usage of the internet has become inevitable also in obtaining information on export marketing. There is no empirical study in the literature which showed the internet-based sources of data on export markets as a whole and examined the effects of these factors on new market knowledge and export market growth capability. This study contributes to the literature by filling this gap. In this study, it was determined that using internet-based information sources for obtaining export market information has an effect on obtaining new market knowledge. Additionally, it was found that using internet- 
based export market information sources has a positive effect on export market growth capability. The results agreed with previous studies which demonstrated the positive effects of obtaining and using export market information on export performance (Hart \& Tzokas, 1999; Köksal, 2008; Souchon \& Durden, 2003; Theodosiou \& Katsikea, 2013; Yeoh, 2000). Finally, it was empirically demonstrated that obtaining new market knowledge has an influence on growth capability in the export market, and similar results were obtained to those reported in the literature (Moen et al., 2008). This outcome has strengthened the existing literature on the topic.

As much as its contribution to the literature, the managerial outputs of this study are also highly important. The issue that it is a highly difficult, costly and as much significant issue to obtain information in international markets has led managers to look for factors that would help them reach faster and more effective information more easily. Some of the most significant ones among these factors are internet-based data sources. Obtaining useful and ready and/or fast acquired information regarding countries and markets and specific and detailed information about prospective customers or rival firms from sources that are used in obtaining export market information such as the databases of states and unions, other databases that require paid membership and consignment sites will provide a great advantage. Similarly, as other internet-based sources, using social media, video sharing, blog and forum websites will provide an advantage for a firm's managers. This is because the virtual world has gained an inevitable and undeniable position for managers as a platform that needs to be examined and researched in the context of determining consumer and rival firm profiles and behaviors for acquiring new market knowledge in international arena. Likewise, websites of customer firms and competitor firms also have the position of data mines for marketers as internet-based information sources. This is because, from these platforms, information on products and their prices, publicity activities, joined organizations and social and economic activities that are carried out (exposition attendance, social responsibility project, etc.) and strategies such as vision and mission may be obtained as raw data to be processed and utilized.

The first condition of growing in the export market is to analyze the market well, and the primary condition for doing this analysis is to obtain current market information. At this point, export companies can obtain new and updated information mentioned above about customers, competitors, general market structure and countries from the internet and they can use this information to grow in export markets. Consequently, in the context of gain favor from digital opportunities that indispensable of our era at the highest level, usage of internet-based sources in obtaining export market information has become not only an opportunity but also a necessity for firms. In the increased competition environment and narrowing domestic markets, obtaining new market knowledge and the supportive influence of this new market knowledge on export market growth capability has become a highly significant issue.

\section{Directions for Future Research and Limitations}

In this study, a model was created by using internet-based sources that are used to obtain export marketing information. Future studies may expand this study by also adding other sources that are not internet-based to the model. Additionally, in the data collection process, the population was selected as Turkey. For future studies, supporting this study by collecting data from other countries may be useful. In addition to this, similar studies may be carried out in different sectors. 


\section{References}

Agrawal, A., Basak, J., Jain, V., Kothari, R., Kumar, M., Mittal, P. A., Modani, N., Ravikumar, K., Sabharwal, Y., \& Sureka, R. (2004). Online marketing research. IBM Journal of Research and Development, 48(5.6), 671-677.

Akın, H. (2019). Yeni işimiz dış ticaret. eKitap Projesi.

Ansoff, H. I. (1988). The new corporate strategy. Wiley.

Azzi da Silva, P., \& da Rocha, A. (2001). Perception of export barriers to Mercosur by Brazilian firms. International Marketing Review, 18(6), 589-611.

Bianchi, C., \& Mathews, S. W. (2016). Internet marketing and export market growth in Chile. Journal of Business Research, 69(2), 426-434.

Brennan, L., Fry, M. L., \& Previte, J. (2015). Strengthening social marketing research: Harnessing "insight" through ethnography. Australasian Marketing Journal, 23(4), 286-293.

Cadogan, J. W., Sundqvist, S., Puumalainen, K., \& Salminen, R. T. (2012). Strategic flexibilities and export performance: The moderating roles of export market-oriented behavior and the export environment. European Journal of Marketing, 46(10), 1418-1452.

Craig, C. S., \& Douglas, S. P. (2001). Conducting international marketing research in the twenty-first century. International Marketing Review, 18(1), 80-90. https://doi.org/10.1108/02651330110398413

Craig, C. S., \& Douglas, S. P. (2005). International Marketing Research (3rd ed.). John Wiley \& Sons Ltd.

Diamantopoulos, A., \& Souchon, A. L. (1999). Measuring export information use: scale development and validation. Journal of Business Research, 46(1), 1-14.

Douglas, S. P. (1989). Evolution of global marketing strategy: Scale, scope, and synergy. Columbia Journal of World Business, 47-58.

Douglas, S. P., \& Craig, C. S. (2006). On Improving the Conceptual Foundations of International Marketing Research. Journal of International Marketing, 14(1), 1-22. https://doi.org/10.1509/jimk.14.1.1

Fornell, C., \& Larcker, D. F. (1981). Structural equation models with unobservable variables and measurement error: Algebra and statistics. Journal of Marketing Research, 18, 382-388.

Fries, J. R. (1982). Library support for industrial marketing research. Industrial Marketing Management, 11(1), 47-51.

Hair, J. F., Anderson, R. E., Tatham, R. L., Black, W. C., Babin, B. J., \& Anderson, R. E. (2010). Multivariate Data Analysis Seventh Edition. In Pearson Prentice Hall. https://doi.org/10.1016/j.ijpharm.2011.02.019

Hair, J. F., Harrison, D. E., \& Risher, J. J. (2018). Marketing Research in the 21st Century: Opportunities and Challenges. Revista Brasileira de Marketing, 17(5), 666-699.

Hair, J. F., Sarstedt, M., Hopkins, L., \& G. Kuppelwieser, V. (2014). Partial least squares structural equation modeling (PLS-SEM) An emerging tool in business research. European Business Review, 26(2), 106-121.

Hart, S., \& Tzokas, N. (1999). The impact of marketing research activity on SME export performance: evidence from the UK. Journal of Small Business Management, 37(2), 63.

Henseler, J., Ringle, C. M., \& Sarstedt, M. (2015). A new criterion for assessing discriminant validity in variance-based structural equation modeling. Journal of the Academy of Marketing Science, 43(1), 115135.

Hou, J.-J., \& Chien, Y.-T. (2010). The effect of market knowledge management competence on business performance: A dynamic capabilities perspective. International Journal of Electronic Business Management, 8(2).

Houghton, K. A., \& Winklhofer, H. (2004). The effect of website and e-commerce adoption on the relationship between SMEs and their export intermediaries. International Small Business Journal, 22(4), 369-388. 
M. Arslandere - S. Ada - İ. Tuncer 12/4 (2020) 3333-3349

Hughes, P., Morgan, R. E., \& Kouropalatis, Y. (2008). Market knowledge diffusion and business performance. European Journal of Marketing, 42(11/12), 1372-1395.

Itani, O. S., Agnihotri, R., \& Dingus, R. (2017). Social media use in B2b sales and its impact on competitive intelligence collection and adaptive selling: Examining the role of learning orientation as an enabler. Industrial Marketing Management, 66, 64-79.

Julien, P., \& Ramangalahy, C. (2003). Competitive strategy and performance of exporting SMEs: An empirical investigation of the impact of their export information search and competencies. Entrepreneurship Theory and Practice, 27(3), 227-245.

Köksal, M. H. (2008). How export marketing research affects company export performance: Evidence from Turkish companies. Marketing Intelligence \& Planning, 26(4), 416-430.

Kotler, P. (1997). Marketing management: Analysis, planning, implementation and control (9th ed.). Prentice Hall.

Kotler, P., \& Armstrong, G. (2003). Fundamentos de marketing. Pearson Educación.

Kotler, P., \& Armstrong, G. (2013). Principles of Marketing (16th Global Edition). Harlow: Pearson.

Kotler, P., \& Keller, K. L. (2016). Marketing Management, 15th Edition. In Pearson Education Limited. https://doi.org/10.1080/08911760903022556

Kumar, V. (2006). International marketing research. In R. Grover \& M. Vriens (Eds.), The handbook of marketing research: Uses, misuses, and future advances (pp. 628-645). Sage Publications.

Lamberton, C., \& Stephen, A. T. (2016). A thematic exploration of digital, social media, and mobile marketing: Research evolution from 2000 to 2015 and an agenda for future inquiry. Journal of Marketing, 80(6), $146-172$.

Laudon, K. C., \& Laudon, J. P. (1999). Management information systems. Prentice Hall PTR.

Le Bon, J., \& Merunka, D. (2006). The impact of individual and managerial factors on salespeople's contribution to marketing intelligence activities. International Journal of Research in Marketing, 23(4), 395-408.

Leonidou, L. C., \& Katsikeas, C. S. (1996). The export development process: an integrative review of empirical models. Journal of International Business Studies, 27(3), 517-551.

Leonidou, L. C., \& Theodosiou, M. (2004). The export marketing information system: an integration of the extant knowledge. Journal of World Business, 39(1), 12-36.

Lim, J.-S., Sharkey, T. W., \& Kim, K. I. (1993). Determinants of international marketing strategy. MIR: Management International Review, 103-120.

Malhotra, N. K. (2018). Marketing Research: Current State and Next Steps. Revista Brasileira de Marketing, 17(5), 647-665. https://doi.org/10.5585/bjm.v17i5.4172

Malhotra, N. K., \& Birks, D. (2007). Marketing Research: an applied approach: 3rd European Edition. Pearson education.

Malhotra, N. K., \& Peterson, M. (2001). Marketing research in the new millennium: Emerging issues and trends. Marketing Intelligence \& Planning, 19(4), 216-232. https://doi.org/10.1108/EUM0000000005560

Mathews, S. W., Bianchi, C., Perks, K. J., Healy, M., \& Wickramasekera, R. (2016). Internet marketing capabilities and international market growth. International Business Review, 25(4), 820-830. https://doi.org/10.1016/j.ibusrev.2015.10.007

Mathews, S. W., \& Healy, M. J. (2006). "From garage to global” The Internet's influence on international market growth, An Australian SME perspective. 51st World Conference, 1-12.

Mochtar, K., \& Arditi, D. (2002). Role of Marketing Intelligence in Making Pricing Policy in Construction. Journal of Management in Engineering, 17(3), 140-148.

Moen, Ø., Madsen, T. K., \& Aspelund, A. (2008). The importance of the internet in international business-to- 
M. Arslandere - S. Ada - İ. Tuncer 12/4 (2020) 3333-3349

business markets. International Marketing Review, 25(5), 487-503. https://doi.org/10.1108/02651330810904053

Nijssen, E. J., Douglas, S. P., \& Calis, G. (1999). Gathering and using information for the selection of trading partners. European Journal of Marketing, 33(1/2), 143-162.

Nunnally, J. C. (1978). Psychometric Theory: $2 d$ Ed. McGraw-Hill.

Perreault Jr, W., Cannon, J., \& McCarthy, E. J. (2013). Basic marketing. McGraw-Hill Higher Education.

Porter, M. E. (2001). Strategy and the Internet Harvard business review. Vol, 79, 62-79.

Poynter, R. (2010). The handbook of online and social media research: Tools and techniques for market researchers (1st ed.). John Wiley \& Sons.

Probst, G., Büchel, B., \& Raub, S. (1998). Knowledge as a strategic resource. Knowing in Firms: Understanding, Managing and Measuring Knowledge, Sage, London, 240-252.

Quinton, S., \& Wilson, D. (2016). Tensions and ties in social media networks: Towards a model of understanding business relationship development and business performance enhancement through the use of LinkedIn. Industrial Marketing Management, 54, 15-24.

Shukla, P. (2008). Essentials of marketing research. Bookboon.

Sinkovics, R. R., Ghauri, P. N., \& Penz, E. (2005). Analysing textual data in international marketing research. Qualitative Market Research: An International Journal, 8(1), 9-38. https://doi.org/10.1108/13522750510575426

Skurpel, D. (2016). Advantages and disadvantages of internet marketing research. World Scientific News, 57, 712-721.

Souchon, A. L., \& Diamantopoulos, A. (1996). A conceptual framework of export marketing information use: key issues and research propositions. Journal of International Marketing, 4(3), 49-71.

Souchon, A. L., \& Durden, G. R. (2003). Making the most out of export information: an exploratory study of UK and New Zealand exporters. Journal of Euromarketing, 11(4), 65-86.

Stokes, R. (2011). E-marketing: The essential guide to digital marketing. Quirk Education: Cape Town, South Africa. Retrieved, 5(22), 2013.

Tarka, P. (2018). The views and perceptions of managers on the role of marketing research in decision making. International Journal of Market Research, 60(1), 67-87.

Tesfom, G., \& Lutz, C. (2006). A classification of export marketing problems of small and medium sized manufacturing firms in developing countries. International Journal of Emerging Markets, 1(3), 262-281.

Teubner, R. A. (2007). Strategic information systems planning: A case study from the financial services industry. The Journal of Strategic Information Systems, 16(1), 105-125.

Theodosiou, M., \& Katsikea, E. (2013). The export information system: An empirical investigation of its antecedents and performance outcomes. Journal of International Marketing, 21(3), 72-94.

Toften, K., \& Hammervoll, T. (2011). International market selection and growth strategies for niche firms. International Journal of Entrepreneurship and Innovation Management, 13(3-4), 282-295.

Voorhees, C. M., Fombelle, P. W., Gregoire, Y., Bone, S., Gustafsson, A., Sousa, R., \& Walkowiak, T. (2017). Service encounters, experiences and the customer journey: Defining the field and a call to expand our lens. Journal of Business Research, 79, 269-280.

Walters, P. G. P. (1996). International market information infusion: Data acquisition behaviour in Norwegian exporters. International Journal of Information Management, 16(6), 437-444.

Wedel, M., \& Kannan, P. K. (2016). Marketing Analytics for Data-Rich Environments. Journal of Marketing, 80(06), 97-121. https://doi.org/10.1509/jm.15.0413

Williams, J. E. M. (2006). Export marketing information-gathering and processing in small and medium-sized 
M. Arslandere - S. Ada - İ. Tuncer 12/4 (2020) 3333-3349

enterprises. Marketing Intelligence \& Planning, 24(5), 477-492.

Wren, B. M., Souder, W. E., \& Berkowitz, D. (2000). Market orientation and new product development in global industrial firms. Industrial Marketing Management, 29(6), 601-611.

Yang, H.-L., \& Tang, J.-H. (2003). A three-stage model of requirements elicitation for Web-based information systems. Industrial Management \& Data Systems, 103(6), 398-409.

Yeoh, P.-L. (2000). Information acquisition activities: A study of global start-up exporting companies. Journal of International Marketing, 8(3), 36-60.

Young, R. B., \& Javalgi, R. G. (2007). International marketing research: A global project management perspective. Business Horizons, 50(2), 113-122.

Zeng, D., Chen, H., Lusch, R., \& Li, S.-H. (2010). Social media analytics and intelligence. IEEE Intelligent Systems, 25(6), 13-16.

Zou, S., \& Stan, S. (1998). The determinants of export performance: a review of the empirical literature between 1987 and 1997. International Marketing Review, 15(5), 333-356.

\section{Appendix A}

Table 6. Identifying Minimum Sample Size

\begin{tabular}{lllll}
\hline & \multicolumn{4}{l}{ Significance level $=0.05$} \\
\cline { 2 - 5 } Maximum number of arrows pointing at a construct & 0.10 & 0.25 & 0.50 & 0.75 \\
\cline { 2 - 5 } & 110 & 52 & 33 & 26 \\
\hline 2 & 124 & 59 & 38 & 30 \\
3 & 137 & 65 & 42 & 33 \\
4 & 147 & 70 & 45 & 36 \\
5 & 157 & 75 & 48 & 39 \\
6 & 166 & 80 & 51 & 41 \\
7 & 174 & 84 & 54 & 44 \\
8 & 181 & 88 & 57 & 46 \\
9 & 189 & 91 & 59 & 48 \\
\hline
\end{tabular}

Source:(Hair et al., 2014) 